\title{
Assessment and effective use of potential of Ukraine in development of industrial filbert cultivation
}

\author{
Satina G. \\ Institute of gardening of NAAS, Sadova Str., 23, Novo-selky Kyiv-Sviatoshyn area Kyiv oblast; e-mail: \\ galina_satina@ukr.net
}

The purpose. To justify potential of the country in industrial filbert cultivation, to mark out series of motive factors and measures for development of the branch. Methods. Dialectic, analysis and synthesis, balance, normative. Results. Probes have shown some problems of domestic production of filbert at availability of significant demand for fruits, favorable natural settings for their growing, and also of some selection and technological development. Conclusions. Organization in Ukraine of industrial production of filbert is an actual problem of development of the consumer market and is also perspective direction for domestic landowners. Creation of industrial gardens with area of 5 thousand hectares will replace foreign produce in the domestic market and allow to dilate export trade.

Key words: consumer market, filbert, production, problems, perspectives, development.

For a long time in the Ukrainian consumer market there is a striking contrast between the massive use of processed hazelnuts, the presence of favorable conditions for its cultivation and almost absolute calm in the production sector. In the nut sector attention is more concentrated on the walnuts. This was facilitated by the narrow range of this crop production and the shortage of walnut supply in the world [1]. At the same time, the hazelnut market is no less attractive and promising for domestic producers. And that's why.

The hazelnut culture is grows well in different parts of Ukraine [2]. This plant is relatively unpretentious to climatic conditions and with proper agrotechnics can provide a generous harvest. For many generations of Ukrainians, these nuts are traditional delicacies: they are consumed fresh and processed. However, the hazelnut consumer market in our country is underdeveloped. Industrial production has come to a standstill for several decades, and the domestic market has been satisfied with imported supplies and gathered in the forest nuts [3]. And this despite the fact that in the neighboring Poland the industry is actively and successfully developing [4]. Such a state of affairs could not leave indifferent many researchers and lovers of culture, amateurs and future professionals of the hazelnut industry.

Active explorations and first attempts were made to adapt successful models of commercial gardens in Ukraine [4-5], selection of effective varieties [6-7], introduction of innovative propagation technologies [8], study cost of creating orchards [9] and market monitoring [10].

At present, there is a need to systematize and supplement partial research, comprehensive assessment of the opportunities and prospects of our country in the industrial cultivation of hazelnuts.

The purpose of scientific research is to outline the potential of the country in the hazelnuts production and to identify a number of internal and external motivators, as well as the measures for the industry development.

The methodological base of research was served by the dialectical method, analysis and synthesis, index, balance, normative, systemic calculus.

The research results testify to the development of hazelnut production in Ukraine. To do this, a multilateral analysis and evaluation of a promising market for our country.

Consumer demand. The fruits of the hazelnut (Corylus maxima L.) belong to the class of dessert nuts, which prefer to consume in both fresh and processed form. The growth of such nuts in the world reaches 0.7-1.1 million tons per year (2007-2016). The main producers are Turkey, Italy, Georgia, the USA and Azerbaijan, which accounts for up to $90 \%$ of total gross harvest (Table 1). 
Almost in their entirety, these countries provide $91.6 \%$ of hazelnut exports to the world market, which is about 200 thousand tons of kernels each year. However, in the USA, as well as in China, Iran, Italy and Chile, despite the large volumes of hazelnut production, the sector is not for export trade: the bulk of the harvested crop is directed to the domestic market (Fig. 1). And Italy and France additionally import 20-30 thousand tons of these nuts each year.

1. Countries - the main producers of hazelnuts in the world, tons

\begin{tabular}{|l|l|c|c|c|c|c|c|}
\hline № & Countries & $\mathbf{2 0 1 3}$ & $\mathbf{2 0 1 4}$ & $\mathbf{2 0 1 5}$ & $\mathbf{2 0 1 6}$ & Average & \% \\
\hline & In the world & 869072 & 707894 & 932718 & 743455 & 813285 & 100,0 \\
\hline 1. & Turkey & 549000 & 450000 & 646000 & 420000 & 516250 & 63,5 \\
\hline 2. & Italy & 112650 & 75456 & 101643 & 120572 & 102580 & 12,6 \\
\hline 3. & Georgia & 39700 & 33800 & 35300 & 29500 & 34575 & 4,3 \\
\hline 4. & USA & 40823 & 32659 & 28123 & 34473 & 34020 & 4,2 \\
\hline 5. & Azerbaijan & 31202 & 30039 & 32260 & 33941 & 31861 & 3,9 \\
\hline 6. & China & 23000 & 23533 & 24872 & 26071 & 24369 & 3,0 \\
\hline 7. & Iran & 20655 & 10098 & 12723 & 16327 & 14951 & 1,8 \\
\hline 8. & Spain & 15300 & 13542 & 11423 & 15306 & 13893 & 1,7 \\
\hline 9. & Chile & 9500 & 9479 & 10814 & 16173 & 11492 & 1,4 \\
\hline 29. & Ukraine & 20 & 10 & 10 & 10 & 13 & 0,0 \\
\hline & Other countries & 27222 & 29278 & 29550 & 31082 & 29283 & 3,6 \\
\hline
\end{tabular}

Consequently, the consumption of hazelnut in these countries is high: in Turkey it is $3.1 \mathrm{~kg}$ per year, in Italy -

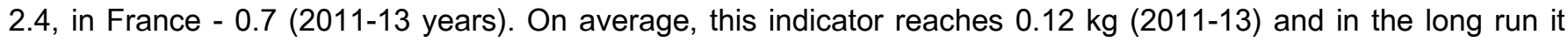
grows along with a production increase and the development of foreign trade.

Major suppliers. The supply of hazelnuts to the world market is increasing at the expense of countries such as Turkey, Georgia, Italy, USA, which have long been engaged in the development of the industry and to this day create new orchards. Thus, in Turkey from 2013 to 2016, the area of fruit-bearing gardens expanded by 14.4 thousand hectares. This country is targeting exports of $57.4 \%$ of its harvest. High growth rate in Georgia: from 2008 to 2016 hazelnut orchards has increased from 10 to almost 20 thousand hectares. And in Azerbaijan over the past 6 years, the area of culture has increased by 8.6 thousand hectares. For comparison, in Ukraine only 0.3 thousand hectares of gardens are officially counted. The new orchards are also active in Chile, Italy, Romania and Moldova. The policy of these countries is quite understandable, because the market of hazelnuts is rather diverse and promising. 


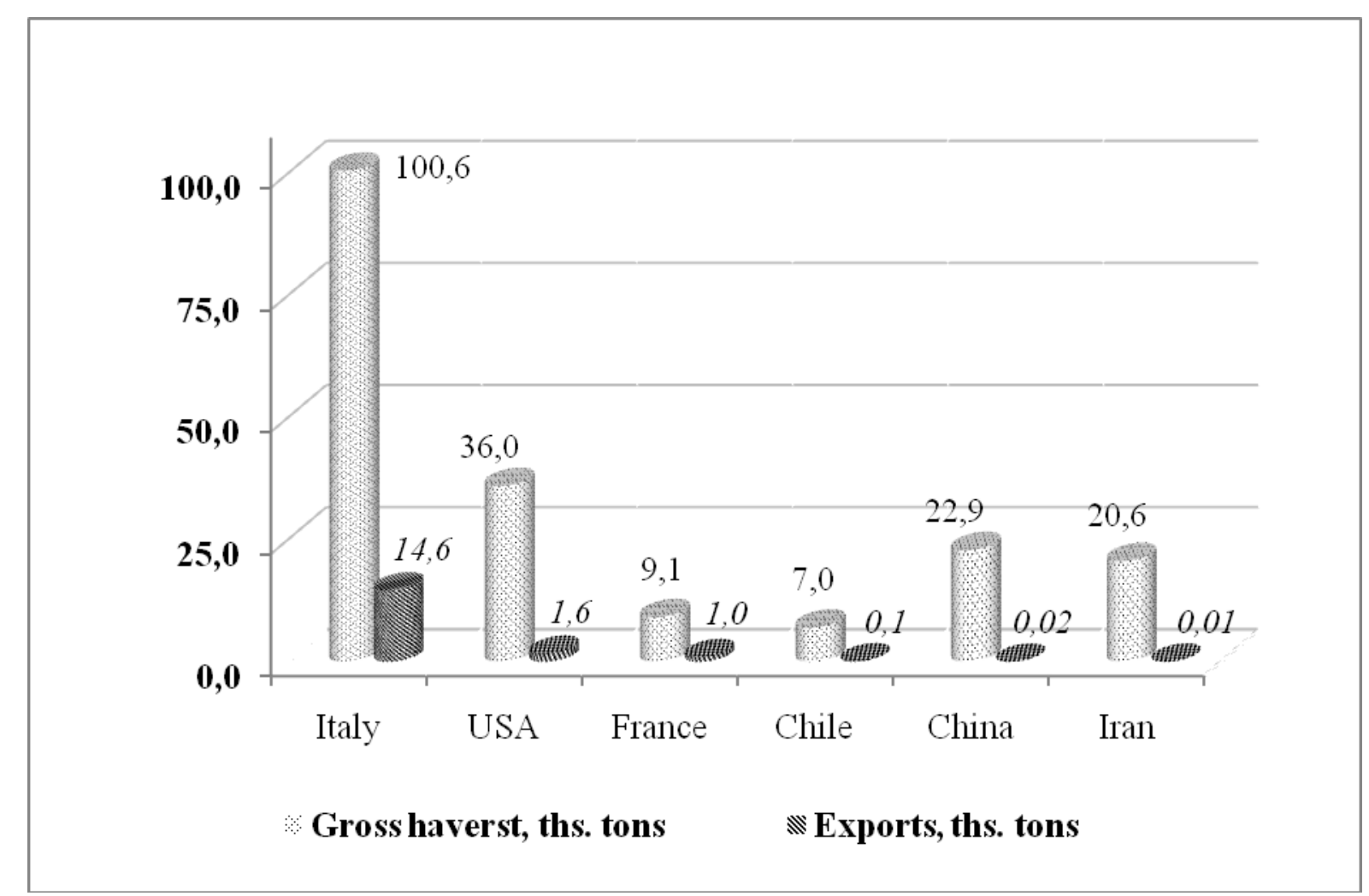

Fig. 1. Volumes of production and export of hazelnuts in high consumption countries, 2011-13

Multilevel market. Nuts of hazelnut culture are in demand in food, confectionery, oily-fatty, pharmaceutical, perfumery, paint and varnish industries. The kernels are consumed in raw form, fried, blanched, sweet, salty, in syrups. Of these, sweets, oils, pasta, milk, cream, coffee, flour, tinctures are made. Vegetable oil is used for the production of soap, candles, varnishes, paints. From wood and shells are getting: finishing materials, gunpowder, coal, linoleum, tannins and more. As a result, consumer demand for hazelnuts is quite lively.

Major buyers. Every year foreign trade attracts about $52.3 \%$ of the world's harvest. The largest importers are Germany (59.5 thousand tons), Italy (31.5), France (20.0), Russia (12.4) and Belgium (11.4), which procures $61.5 \%$ of the world's supplies nut market. In cash equivalent, it is 937 million dollars USA (average for 2011-2013).

Internal needs. Ukraine is also among the importers of hazelnuts. Since 2010, the domestic market has received a total of 27.2 thousand tons of nuts with value of 84.7 million dollars USA. This provided domestic consumption of $0.1 \mathrm{~kg}$ per person per year. Recall that in countries with a high culture of nutrition, the indicator is much higher, in particular in Western Europe - 1.15 kg, in the South - 1.25 kg (Fig. 2). 


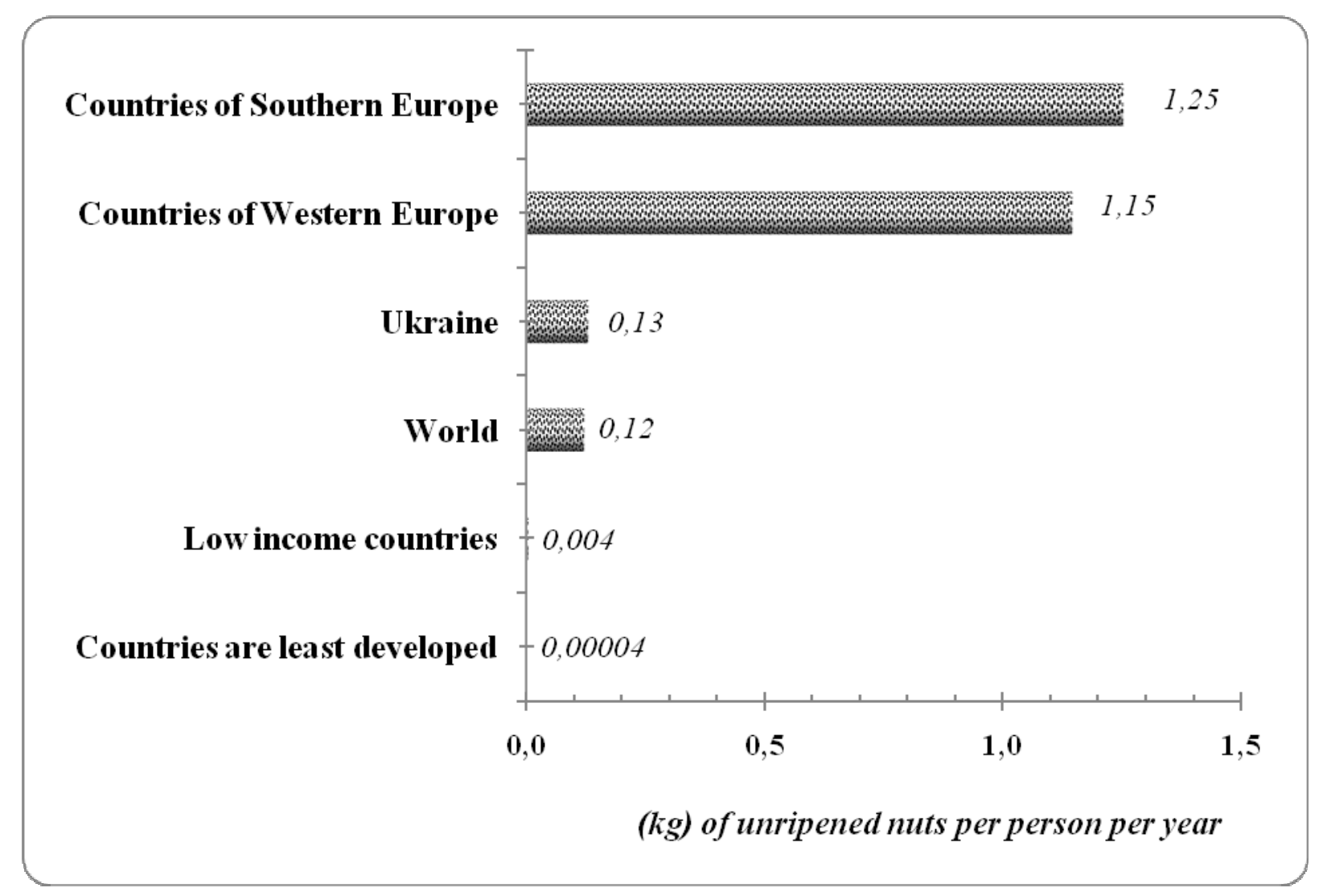

Fig. 2. The level of hazelnuts consumption in 2013 ( $\mathrm{kg} /$ person), according to the FAO

Food Balance. Details of the domestic market of hazelnuts explain the food balance. It shows that import deliveries form up to $100 \%$ of the country's consumer fund, and domestic production is almost absent. The volume of export (re-export) in such situation remains insignificant (Table 2).

2. Food balance of hazelnut (2013-2016), ths. centner

\begin{tabular}{|l|c|c|c|c|}
\hline \multicolumn{1}{|c|}{ Balance Articles } & $\mathbf{2 0 1 3}$ & $\mathbf{2 0 1 4}$ & $\mathbf{2 0 1 5}$ & $\mathbf{2 0 1 6}$ \\
\hline Production & 0,20 & 0,10 & 0,10 & 0,10 \\
\hline Stock change at the year's end & $-0,2$ & $-0,2$ & $-0,4$ & $-0,1$ \\
\hline Exported & 0,7 & 0,0 & 0,3 & 0,0 \\
\hline Imported (import) & 61,1 & 32,5 & 13,0 & 16,3 \\
\hline Total resources & 60,8 & 32,8 & 13,2 & 16,5 \\
\hline Spent on food & 0,3 & 0,2 & 0,1 & 0,1 \\
\hline Loss of production & 0,3 & 0,1 & 0,1 & 0,1 \\
\hline Processing for non-food purposes & 1,2 & 0,7 & 0,3 & 0,3 \\
\hline Consumption Fund & 59,0 & 31,9 & 12,8 & 16,0 \\
\hline
\end{tabular}

Against the background of the given figures, the question is: why, with the presence of a significant number of domestic varieties, favorable natural conditions for nut production and a strong base of agrotechnological knowledge, our country, instead of serving as a donor, is an acceptor in the hazelnut market?

The answer lies in the fact that for a long time in Ukraine the nut-fruit were treated as non-industrial crops. Certain changes have occurred with the development of market relations. Active external demand for walnuts stimulated the development of the industry precisely in this direction. Even with the low merchantable quality of our products in comparison with world standards, the external market absorbs it, mostly in the form of raw materials. Thus, in 2012-16, the share of walnuts exports amounted to $72 \%$ of gross harvest. But for the hazelnut, this segment of trade is more difficult to master due to the strong development of the industrial industry in a number of countries in Asia, America and Europe. Competition of hazelnut suppliers in high-yielding markets is high. Domestic producer also lacks technological and marketing agility for a worthy competition for such a consumer. 
Importation can become the niche that will be able to mobilize domestic efforts and stimulate the development of hazelnut production. The prospects of the industry in this case are related to the creation of the first 5 thousand hectares of industrial orchards. Hence, the task of efficient organization of own production arises. Is this possible? Let's try to answer based on the estimation of typical hazelnut growth technologies.

Creation of hazelnut orchards. According to the experts of the Institute of Horticulture of the National Academy of Agrarian Sciences of Ukraine, the organization of commercial production of hazelnuts should be considered only in conditions with irrigation. The period of orchards creation with the scheme of trees $6 \times 6 \mathrm{~m}$ is 6-7 years, and the exploitation - more than 25 years. The expected yield level is closely correlated with the selection of varieties and is 1.5-2.5 $\mathrm{t} / \mathrm{ha}$. A typical project involves soil preparation, orchards planting, fence installation, irrigation arrangement and annual care of young plants until they are introduced into marketable fruiting. Creating 1 hectare of such plantations will cost 433.1 thousand UAH (as of 01.02.2018). At the same time, the spending of labor will be -755 man-hours, mineral and organic fertilizers - 127.6 tons, fuel - 3.4 tons and water - about 3.2 tons.

Efficiency of production. Commodity fruiting in the orchards is associated with the achievement of breakeven production and is expected for 7 years of vegetation with a yield of over $1.1 \mathrm{t} /$ ha (profitability level of 9.1\%). During the next 3-8 years productivity will increase to 2.0-2.5 t/ ha. Typical technology involves soil retention, plant nutrition, disease and pest protection, mechanized harvesting and primary nut harvesting. All this will cost 82.5 thousand UAH each year at a yield of $2.5 \mathrm{t} / \mathrm{ha}$. Under conditions of nuts sale at a price of 9.5 thousand UAH for a ton of higher commodity grade and 8.3 thousand $\mathrm{UAH}$ per tone of the first commodity grade, the proceeds from the sale of the harvest will be 234.5 thousand UAH from 1 ha of the industrial orchards. Taking into account the expenses incurred and taxes under the simplified tax regime (for agricultural producers - group 4), the net profit will amount to 102.0 thousand $\mathrm{UAH}$, the profitability rate will reach $123.6 \%$ and the payback period of investments is 3.3 years.

Compressed tree planting schemes with a rectangular placement system in the series are becoming more common - they are usually $6 \times 4$ and $5 \times 4 \mathrm{~m}$. We give the economic evaluation of the creation and cultivation of hazelnut orchards under the scheme of $5 \times 4 \mathrm{~m}$. The cost of 1 ha plantation will be 486,7 thousand UAH. Unprofitable production of young orchards will result in the yield of more than $1.4 \mathrm{t} /$ ha: that is on the 7th year of vegetation with profitability $-25.5 \%$. A full harvest is expected at a level of $3.5 \mathrm{t} / \mathrm{ha}$. In its cultivation under irrigation conditions it is necessary to spend 101.5 thousand $\mathrm{UAH}$. The income from 1 hectare of hazelnuts will be 328.3 thousand $\mathrm{UAH}$, net profit - 156.9 thousand UAH and the level of profitability $-154.6 \%$. Payback period of attracted investments $-2,5$ years.

Industry development. In the scale of the country, the effect will be measured as follows. Creating 5 thousand hectares of hazelnut orchards will allow receiving an additional 17,500 tons of high-quality nuts every year. On a per capita basis, the level of production will increase from 0.0002 to $0.4 \mathrm{~kg}$. Expected production volumes will not only block imports, but will also contribute to the development of trade in foreign markets. The total investment needs for the creation of 5,000 hectares of hazelnut orchards reach 2.4 billion $\mathrm{UAH}$, and cash flow receipts (profits and funds of the depreciation fund) are estimated at 650-980 million UAH annually. Along with the food and economic is expected to have a social effect. Due to additional jobs, employment in this agro-sector will increase by $650 \%$ annually to 2017 and will eventually reach 1.1 thousand people (under full employment conditions).

\section{Conclusions}

Consequently, the placing of marketable hazelnuts is an urgent need for the development of the domestic consumer market and a promising business for the country's farmers. At the same time, this case requires a careful and balanced approach in the process of varieties selection, technologies of their cultivation, creation of industrial infrastructure and marketing activities. This should focus on further scientific research.

\section{Bibliography}

1. Global Statistical Review 2014-2015: Nut and Dried Frut - Spain: INC, 2016. - 76 p.

2. Satina H.M. Oleshchenko F.H., Koshlakova N.M. et al. (2011). Naukovi osnovy ta skladovi haluzevoyi prohramy rozvytku horikhivnytstva v Ukrayini. Kyiv: Lohos. $100 \mathrm{~s}$. [In Ukrainian].

3. Satina H.M., Popova O.P. (2017). Fundukovomu sadu buty. Ahronavihator. .10. S.42-45. [In Ukrainian]. 
4. Teleha A. (2016). Zolotoy oreshek ukraynskykh proyzvodyteley. Oreshnyk. 1. S. 34-36. [In Russian].

5. Sheyko M. (2017). "Fylbert": stavka na funduk. Oreshnyk. 1. S. 60-63. [In Russian].

6. Kosenko I.S., Opalko A.I., Balabak O.A. et al. (2017). Hazelnut breeding in the National Dendrological Park "Sofiyivka" of the NAS of Ukraine. Plant Varieties Studying and protection. 3 (13), P. 245-251.

7. Slyusarchuk V.Ye. (2015). Otsinyuvannya sortiv i kloniv funduka selektsiyi Ukrayins'koho naukovo-doslidnoho instytutu lisovoho hospodarstva ta ahrolisomelioratsiyi im. H.M. Vysots'koho v DSDLTs «Veseli Bokoven'ky». Lisivnytstvo i ahrolisomelioratsiya. Vyp. 127. S. 92-97. [In Ukrainian].

8. Yaremko N.O., Karas A.la., Barabash L.O. (2016). Ekonomichna efektyvnist' vyroshchuvannya vidsadkiv funduka $v$ riznykh konstruktsiyakh matochnyka. Zbirnyk materialiv Mizhnarodnoyi naukovo-praktychnoyi konferentsiyi "Stan i perspektyvy rozrobky ta vprovadzhennya resursooshchadnykh, enerhozberihayuchykh tekhnolohiy vyroshchuvannya sil's'kohospodars'kykh kul'tur". Dnipro, S. $118-119$. [In Ukrainian].

9. Panasenko H.V. (2010). Otsinka vytrat hroshovykh koshtiv i zatrat pratsi na vyroshchuvannya funduka. Ahroinkom. 10-12. S. 37-38. [In Ukrainian].

10. Salo I.A. (2012). Osnovni tendentsiyi rozvytku rynku horikhoplidnykh v Ukrayini ta sviti. Problemy ekonomiky. 4. S. 9-12. [In Ukrainian]. 